\title{
NOTES ON PHILONOTIS (BARTRAMIACEAE, MUSCI). 15. PHILONOTIS ON MT. KILIMANJARO, TANZANIA
}

\author{
ЗАМЕTКИ О PHILONOTIS (BARTRAMIACEAE, MUSCI). \\ 15. PHILONOTIS НА ГОРЕ КИЛИМАНДЖАРО, ТАНЗАНИЯ \\ TIMO KOPONEN ${ }^{1}$ \\ ТИМО КОПОНЕН ${ }^{1}$
}

Abstract

\begin{abstract}
Altogether ten species of Philonotis (Hedw.) Brid. have been recorded from Mt. Kilimanjaro, however only six of them are confirmed. The Kilimanjaron specimens named as $P$. fontana and $P$. tomentella differ from the representatives of the high arctic to boreal populations, and are excluded. A key to the accepted species and descriptions and illustrations of P. schroederi and P. tricolor are provided. P. platyneura is synonymized with $P$. tricolor. The relationship of $P$. globosa with $P$. schroederi needs a further study and the presence of $P$. dregeana on Kilimanjaro needs to be confirmed. Additional notes are given of $P$. falcata (W.J. Hook.) Mitt., P. heleniana (Mitt.) Herz., P. helenica (Besch.) Par. and P. usambarica Broth. Lectotypes are designated for P. tricolor and Bartramia gemmascens Müll.Hal. (= Philonotis gemmascens) and Philonotis section Leiocarpus Broth. The taxonomy of the sections of Philonotis is discussed; two sections, Philonotis and Philonotula (Bruch, Schimp. \& Gümbel) A. Jaeger include most of the species. P. dregeana (Müll.Hal.) A. Jaeger, P. gemmascens (Müll.Hal.) Par., P. globosa (Müll.Hal.) D.G. Griffin \& W.R. Buck, P. marangensis Broth. (= P. hastata (Duby) Wijk \& Margad.) and P. schroederi Broth. belong to the section Philonotula. P. fontana (Hedw.) Brid., P. platyneura P.Varde, P. tomentella Molendo and P. tricolor (Müll.Hal.) Par. are the species of the section Philonotis.
\end{abstract}

Резюме

Для горы Килиманджаро приводилось 10 видов из рода Philonotis (Hedw.) Brid., однако только 6 из них подтверждаются в данной ревизии. Образцы с Килиманджаро, определенные как $P$. fontana и P. tomentella, отличаются от растений из арктических и бореальных популяций, и эти виды должны быть исключены из списка. Дан ключ для принимаемых видов, а также описания и иллюстрации для $P$. schroederi и $P$. tricolor. P. platyneura синонимизируется с $P$. tricolor. Взаимоотношения P. globosa с P. schroederi нуждаются в дальнейшем изучении; для $P$. dregeana необходимо подтвердить его присутствие на Килиманджаро. Приводятся дополнительные заметки, касающиеся P. falcata (W.J. Hook.) Mitt., P. heleniana (Mitt.) Herz., P. helenica (Besch.) Par. и P. usambarica Broth. Выбраны лектотипы для P. tricolor, Bartramia gemmascens Müll.Hal. (= Philonotis gemmascens) и Philonotis section Leiocarpus Broth. Обсуждается таксономия секций рода Philonotis; две секции, Philonotis и Philonotula (Bruch, Schimp. \& Gümbel) A. Jaeger включают большинство видов. P. dregeana (Müll.Hal.) A. Jaeger, P. gemmascens (Müll.Hal.) Par., P. globosa (Müll.Hal.) D.G. Griffin \& W.R. Buck, P. marangensis Broth. (= P. hastata (Duby) Wijk \& Margad.) и P. schroederi Broth. относятся к секции Philonotula. P. fontana (Hedw.) Brid., P. platyneura P.Varde, P. tomentella Molendo и P. tricolor (Müll.Hal.) Par. принадлежат секции Philonotis.

KEYWORDS: Africa, Bartramiaceae, Kenya, Mt. Kilimanjaro, nomenclature, Philonotis, sections of Philonotis, Tanzania, taxonomy

\section{INTRODUCTION}

According to Kis (1985), altogether 393 species of mosses and nine species of Philonotis (Hedw.) Brid. have been recorded from Mt. Kilimanjaro, Tanzania: P. fontana (Hedw.) Brid., P. gemmascens (Müll.Hal.) Par., P. globosa (Müll.Hal.) D.G. Griffin \& W.R. Buck (as Bartramidula g.), P. marangensis Broth. (= P. hastata (Duby) Wijk \& Margad.), P. platyneura P.Varde, P. schroederi
Broth., P. tomentella Molendo and P. tricolor (Müll.Hal.) Par. In addition, Philonotis dregeana (Müll.Hal.) A. Jaeger was listed from Mt. Kilimanjaro by Pócs (1994). The specimens of Philonotis section Philonotis, P. fontana, $P$. platyneura and $P$. tomentella are revised and other taxa discussed.

The specimens of Philonotis fontana and P. tomentella for this revision came from the Cryptogamic Her-

1 - Finnish Museum of Natural History LUOMUS, Botany Unit (Bryology), P.O. Box 7, FI-00014 UNIVERSITY OF HELSINKI, Finland; and Finnish-Chinese Botanical Foundation, Mailantie 109, FI-08800 LOHJA, Finland 


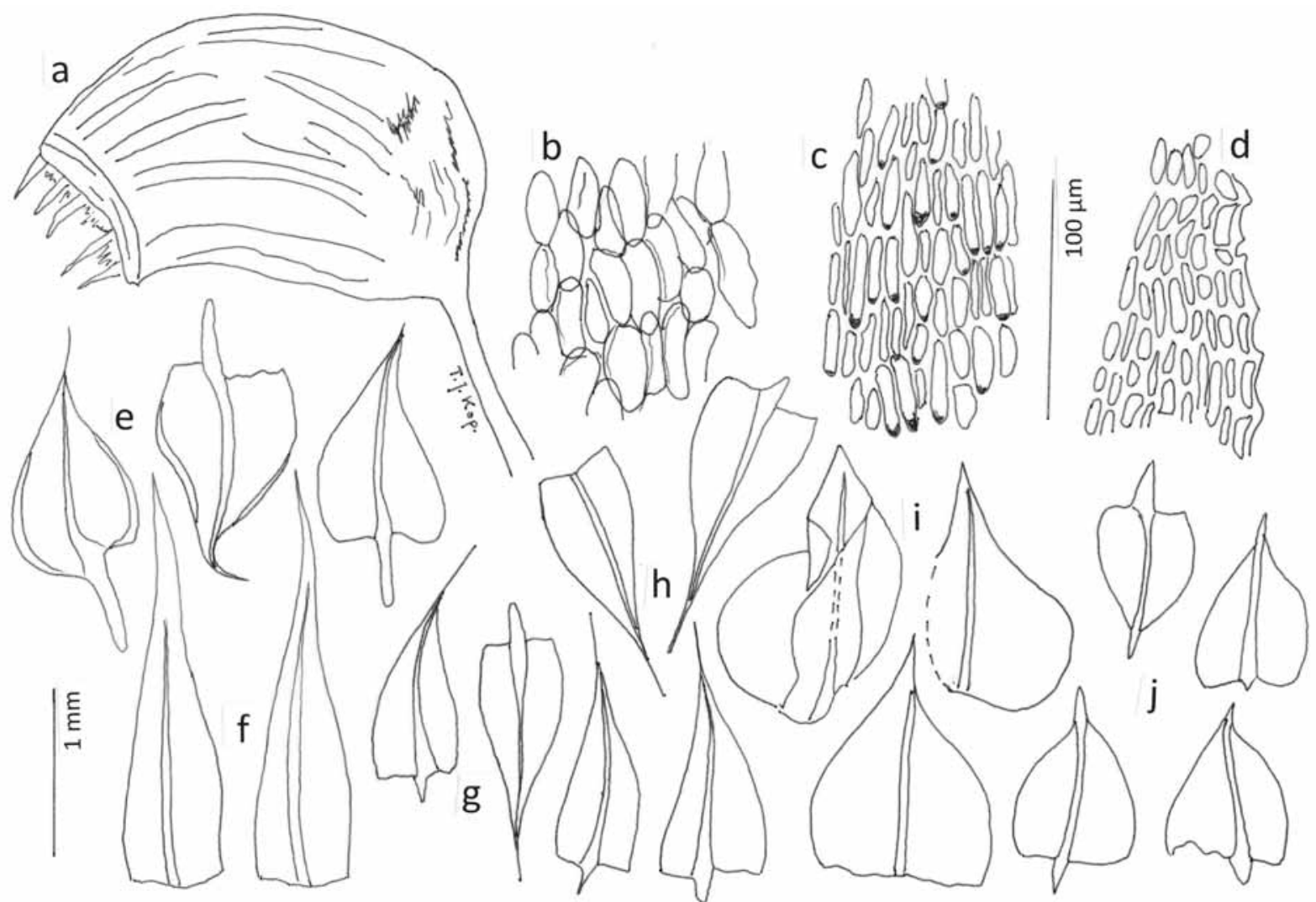

Fig. 1. Philonotis tricolor (Müll.Hal.) Par. (a-i: from KRAM-B 102454; j: from KRAM-B 047403, P. tricolor modification "platyneura"). a - capsule, dry; b - basal laminal cells; c-median laminal cells; d - upper leaf cells at margin; $\mathrm{e}$ - three leaves from female stem; $f$ - perichaetial leaves; $g$ - three leaves from innovation branch of female plant; $h$ - three leaves from male stem; $i$ - three perigonial leaves; $j$ - four stem leaves from depauperate plant. The scale " $1 \mathrm{~mm}$ " for a and $\mathrm{e}-\mathrm{j}$, and the scale " $100 \mu \mathrm{m}$ " for $\mathrm{b}-\mathrm{d}$.

barium, Botanical Department of Károly Esztrházy College (EGR) and the Laboratory of Bryology, Institute of Botany, Polish Academy of Sciences (KRAM). In addition, the collections in $\mathrm{H}$ and $\mathrm{H}-\mathrm{BR}$ were studied.

The SECTIONS OF PHILONOTIS (HEDW.) BRID.

Griffin \& Buck (1989) discussed on the taxonomy of Philonotis in relation to the genus Bartramidula Bruch \& Schimp. The small size and globose to ovate, erect capsule with reduced peristome or eperistomate capsule have been the major characters separating Bartramidula from Philonotis. However, there is no gametophytic diagnostic character distinguishing Bartramidula from Philonotis. Leaf shape, cell size, degree of costa percurrency and papillosity of leaves do not represent major differences from those found in Philonotis. Griffin \& Buck (1989) concluded that most of the species of Bartramidula should be relocated under Philonotis section Leiocarpus Broth., originally distinguished by Brotherus (1924) by having single peristome. However, Philonotis section Bartramidula antedates the section Leiocarpus (see below). The species of Bartramidula are mostly small-sized plants growing on ephemeral habitats. The erect capsule with reduced peristome is a common phenomenon of such plants in other groups of mosses, for instance in some genera of the Pottiaceae. The evolution in Philonotis from a horizontal capsule with complete peristome to erect capsule with reduced peristome may have taken place several times in different populations. Bartramidula, including the species of the section Leiocarpus, is heterogeneous and hardly a monophyletic entity. In Virtanen's (2003, fig. 1) study, using both morphology and DNA sequence data, Philonotis bartramioides (Griff.) D.G. Griffin \& W.R. Buck (= Bartramidula bartramioides) is included in the same clade with $P$. falcata (W.J. Hook.) Mitt., P. thwaitesii Mitt. and P. vescoana (Besch.) Par. of the section Philonotula.

In addition to the section Leiocarpus, Brotherus (1924) had sections Philonotula (Bruch, Schimp. \& Gümbel) A. Jaeger, Catenularia (Müll.Hal.) Par., Eu-Philonotis Braithw. (nom. illeg.), Pseudo-Mniobryum Broth. and Pseudo-Philonotis M. Fleisch. Pseudo-Philonotis is now regarded as a genus of its own, Fleischerobryum Loeske, and the sections Catenularia (Philonotis scabrifolia (Hook.f. \& Wils.) Braithw.) and Pseudo-Mniobryum (Philonotis vagans (Hook.f. \& Wils.) Mitt.) have only one species each. The species of Brotherus' (1924) section "Eu-Philonotis", which have major papillae at the proximal end of leaf cells, form the present section Philonotis, and the species with the papillae at the distal end of leaf cells are in the section Philonotula. By this, Philonotis contains only two sections with a large number of species, the sections Philonotis and Philonotula. 


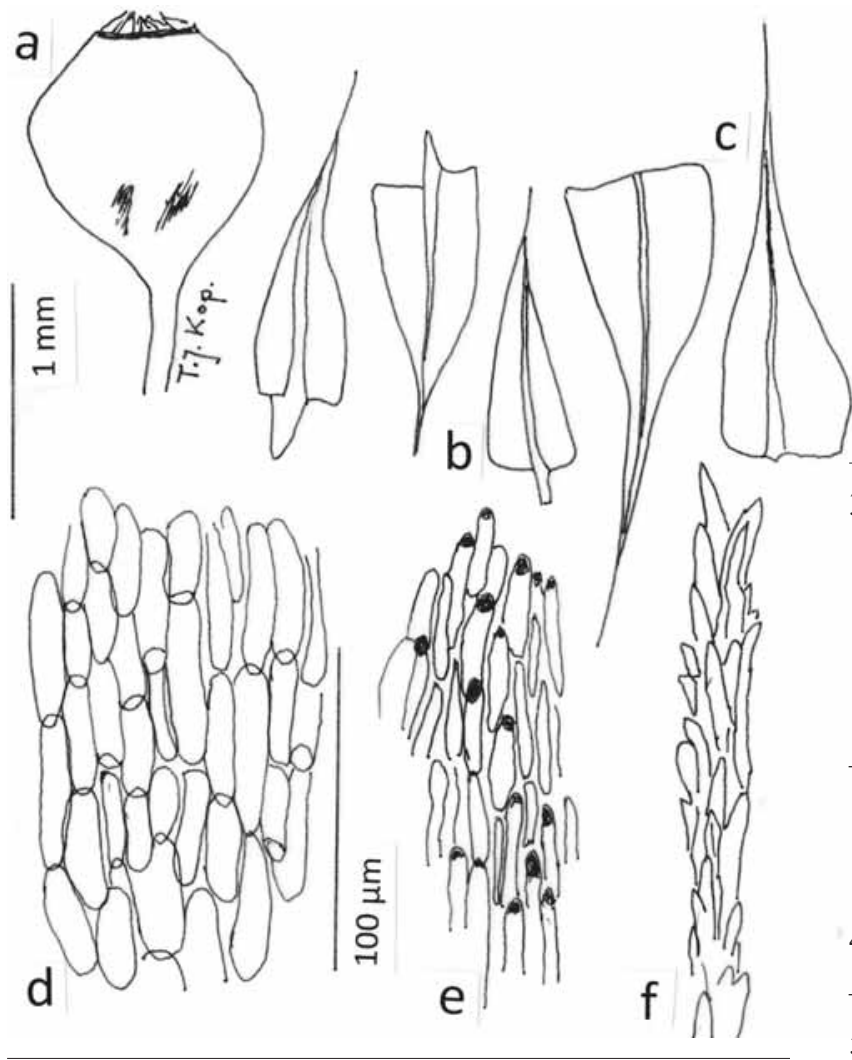

These sections were distinct in a phylogenetic analyses using DNA methods (Koponen et al., 2012).

The globose to ovate and erect capsule remains to be a useful specific character in Philonotis. However, the specimens of Philonotis with sporophytes are not common. Usually the identification based on the characters of fully developed sterile specimens is possible. Therefore here, as well as in my previous studies of Philonotis (e.g. Koponen \& Norris, 1996; Koponen, 1998, 2009, 2010a, b; Koponen et al., 2012), the vegetative characters are paid much attention and the keys are based mainly on the gametophytes.

\section{KEY TO THE SPECIES}

1. Upper leaf cells with major mammillae/papillae at proximal cell end; double crenulate teeth on lower leaf border (two adjoining cells form a teeth)

P. tricolor

- Upper leaf cells with major mammillae/papillae at distal cell end; lower leaf border entire, serrate or serrulate and often geminate

2

2. Capsule \pm erect, globose and smooth when dry; inner peristome lacking, outer peristome reduced; basal leaf cells bulging at proximal cell ends, apical cells narrow, papillose at distal cell ends ... P. schroederi

- Capsule \pm horizontal, ovoid - gibbose and striate when dry; peristome complete with both inner and outer peristome; all cells papillose/mammillose at distal cell end.

3. Basal leaf cells or all leaf cells \pm thin-walled or firm, quadrate, rectangular or rhomboidal, nearly smooth or low mammillose; nerve not reaching apex or percurrent in shortly acute innovation leaves, often shortly excurrent on acute stem leaves; marginal teeth blunt

- Basal leaf cells thin- or firm-walled, mostly rectangular to linear, mammillose or papillose; innovation leaves acute; nerve percurrent or excurrent in all leaves; leaf marginal teeth sharp .. 5

4. Costa nearly smooth P. hastata

- Costa rough by many large teeth ...... P. usambarica

5. Leaves distinctly in five rows (best seen on imbricate innovations), falcate and carinate, triangular and acute with percurrent nerve or acuminate with excurrent nerve, nerve flexuose; leaf marginal teeth mostly single P. falcata

- Leaves not in rows, straight or slightly falcate-secund or flexuose, plane or slightly concave; leaf marginal teeth single or geminate-dentate; nerve straight P. gemmascens

\section{PHILONOTIS OF MT. KILIMANJARO}

\section{Philonotis section Philonotis}

Type: Philonotis fontana (Hedw.) Brid.

Most of the species of the section Philonotis are holarctic, boreal to temperate taxa (Koponen et al., 2012). A number of taxa belonging to the section Philonotis have been reported from subantarctic areas and synonymized with Philonotis polymorpha (Müll.Hal.) Kindb. (Ochyra et al., 2008). P. caespitosa Molendo is known from $\mathrm{S}$ Africa (Koponen, 2003). As to P. helenica (Besch.) Par., synonymized with $P$. fontana, see below. Many specimens collected on the high mountains of Central Africa have been named by the names of the northern species, as $P$. fontana and P. tomentella. These are here treated as P. tricolor. P. platyneura P.Varde is synonymized with it. Some of the specimens named as $P$. fontana or P. tomentella proved to belong to the section Philonotula.

\section{Philonotis tricolor (Müll.Hal.) Par. (Fig. 1)}

Ind. Bryol. 931. 1897. - Bartramia tricolor Müll.Hal., Flora 73: 478. 1890. - Lectotype (designated here): [From the protologue:] Africa or. trop., monte Kilima-Ndscharo, 
inter 3000-4800 m cum Bryo bicolori: Dr. Hans Meyer lg. 1889; [From the label:] Kilimandscharo, H. Meyer (H-BR3113 003!). - The specimen contains only one stem.

Philonotis platyneura P.Varde, Ark. Bot. Ser. 2, 3: 170, fig. 24. 1955, syn. nov. - Holotype: Uganda. Ruwenzori, Bujuku Valley, at a small brook from the glacier on the S.W. slope of Mt. Speke, $4150 \mathrm{~m}$, O. Hedberg $427 b$ (not seen).

Plants brownish, small- to medium-sized, in tomentose tight tufts, shoots $1-5 \mathrm{~cm}$; branched by $2-5$ innovations below archegonia; leaves 1.2-2.5 mm long and $0.5-1.0 \mathrm{~mm}$ broad, not arranged in rows; stems of the growing season imbricate, leaf bases erect, leaf apices arcuate or flexuose to different directions; leaves concave or carinate, from ovate or broadly ovate base gradually tapering to acuminate apex, narrow distal part of leaf $1 / 3$ of leaf length; leaf margins revolute and marginal teeth double crenulate at basal part, geminate to serrulate at distal leaf; old stems leaves distant; costa strong, 75-80 $\mu \mathrm{m}$ broad near leaf base with small mammillae at apical part, bending and excurrent; leaf areolation translucent in basal part of leaf, dim at apical part; in basal part of leaf cells short rectangular - rhomboidal, 10$20 \times 25-37 \mu \mathrm{m}$, in rows parallel to costa, thin-walled; apical leaf cells $5-10 \times 17-37 \mu \mathrm{m}$ with firm walls; all cells have mammilla/papilla at proximal end of cells.

Dioicous. Perichaetial leaves from ovate base long acuminate. Perigonia disc-shaped, perigonial leaves concave at base, acute to acuminate, fragile; leaves below perigonia erect, and not much different from vegetative leaves on sterile and female shoots. Seta $3-4 \mathrm{~cm}$; capsule ca. $2 \mathrm{~mm}$ long, horizontal, gibbose and striate when dry. Peristome complete. Spores ca. $25 \mu \mathrm{m}$.

The description above is based on well-developed plants. The papillae of leaf cells at the proximal cell end and the double crenulate leaf margin at lower leaf show that Philonotis tricolor is a member of the section Philonotis. The leaves on old stems are distant so that the stem is visible between the leaves. In the extremely depauperate forms the broadly ovate leaf base tapers abrubtly to a short, straight and strong excurrent costa and the leaves are carinate like the leaves in $P$. falcata (W.J. Hook.) Mitt. of the section Philonotula. Such form was described and illustrated as P. platyneura (Potier de la Varde, 1957). Most of the other Philonotis species have flat or concave leaves. The change from hook-like shorter and distant leaves at basal stem to gradually tapering younger leaves is gradual. These characters separate $P$. tricolor from the other species of the section Philonotis. Some of the specimens (Philonotis flagellifera Broth. in herb., Pócs 6927AG, Uhlig s.n.) have flagelliferous shoot apices, similar to those in Aulacomnium palustre (Hedw.) Schwägr.

Specimens of Philonotis tricolor were collected from the high central African mountains Mt. Elgon, Mt. Ken- ya, Mt. Kilimanjaro and Mt. Ruwenzori at 2500-4300 $(-4800) \mathrm{m}$. The habitats are in moist conditions on cliffs with trickling water, stream shores or bogs (see the label information below).

Specimens studied: KENYA. Mt. Kenya, upper Teleki Valley, on soil and muck along stream leaving Lake Höhnel, 4200 m, 21.6.1984 J. Spence 2583b (EGR); on wet soil along the shore of Höhnel Lake, Spence 2568 (KRAM-B 066472), Spence $2569 \mathrm{~b}$ (EGR); Sirimon Track, subalpine moorland, $3300 \mathrm{~m}$, 21.12.1975 S. Rojkowski 91 (EGR, KRAM-B 047403); Mt. Elgon, E slope, on banks of a small stream below the summit, 4300 m, 15.12.1975 S. Rojkowski 56 (KRAM 047401).

TANZANIA. Kilimanjaro Mts., Shira Plateau, in a small gorge S of Shira Hut, on irrigated rocks, $3660 \mathrm{~m}, 27.6 .1976$ T. Pócs 6927/AG (EGR, KRAM-B 031060); Kilimandscharo, Garanga Lager am Garanga Bach auf Fals, 24.10.1901 C. Uhlig (H-BR3088018, as P. flagellifera); Kilimanjaro National Park, Karanga Valley at side of Kibo summit, on irrigated rocks of spring bogs and streambed, 3900-4000 m, 4.3.1985 T. Pócs 6992/I (EGR); Barrango Valley on the SW side of Kibo, on boggy ground of a Senecio cottonii stand $3950 \mathrm{~m}, 22.9 .1972 \mathrm{~T}$. Pócs \& P. Lawrence 6796/B (EGR); near Barrango Hut, SW of Kibo, on rocks irrigated by a stream, $3850 \mathrm{~m}$, Pócs \& Lawrence 6794/G (EGR); Kilimanjoro Mts., Marangu Route, above Mandara Hut, on ground in montane rain forest in shady ravine, 2500 m, 20.1.1976 B. Zemanek (KRAM 047405); Rocky gorge with streamlet and scattered giant Senecio kilimanjiri $2.5 \mathrm{~km}$ east of Horombe Hut, $3480 \mathrm{~m}$, lat. $3^{\circ} 08^{\prime} \mathrm{S}$, long. $37^{\circ} 26^{\prime} \mathrm{E}$, on humus in rock fissures in moist situation, 16.6.1988 T. Pócs, R. Ochyra \& H. Bednarek-Ochyra 88127/P (= R. Ochyra \& T. Pócs 1993, Bryophyta Africana selecta Ser. V, no. 115 (EGR, H3107005, KRAM-B 102454); In the valley near Horombo Hut/ Peter's Hütte, Subalpine Senecio - Carex monostachya - Alchemilla moorland, on peaty ground, 3700-3800 m, 19.9.1970 T. \& S. Pócs $6248 / J$ (EGR); S slope of Mawenzi, deep gorge in the ericaceous zone, on basaltic rock, $3440 \mathrm{~m}, 15.9 .1970 \mathrm{~T}$. \& S. Pócs $6247 / C$ (EGR); Near Morombo Hut, on stone walls, 3760 m, 17.1.1976 S. Rojkowski 312 (EGR, KRAM-B 047401); Above Morombo Hut, subalpine Senecio cottonii moorland, 4000 m, 19.1.1976 S. Rojkowski 332 (KRAM-B 047402).

UGANDA. Ruwenzori, partie supérieure de la Vallée de la Bujuku, rochers abruptes du côté Mt. Margherite, 4200 m, 26.1.1974 S. Lisowski 3455, 5084 (KRAM); Ruwenzori, Stuhlman Pass, 1.2.1874 S. Lisowski 5148 (KRAM).

Philonotis section Philonotula (Bruch, Schimp. \& Gümbel) A. Jaeger

Ber. Thatigk. St. Gallischen Naturwiss. Ges. 187374: 78 (Gen. Sp. Musc. 1: 540). 1875. - Bartramia sect. Philonotula Bruch, Schimp. \& Gümbel, Bryol. Eur. 4: 1. 1851 (fasc. 46-47 Consp. vol. 4: III). - Philonotis subgen. Philonotula (Bruch, Schimp. \& Gümbel) Schimp., Syn. ed. 2. 424 1876. -Type: Philonotis rigida Brid.

Bartamidula Bruch \& Schimp. in Bruch, Schimp. \& Gümbel, Bryol. Eur. 4: 55 1846. (fasc. 29-30). - Philonotis section Bartramidula (Bruch \& Schimp.) Mitt., Linn. Soc. Bot. 7: 153. 1863. - Type: Bartramidula wilsonii (Bruch, Schimp. \& Gümbel) Mitt. $=$ P. rigida Brid.

Philonotis sect. Leiocarpus Brotherus, Nat. Pflanzenfam. 1(3): 645. 1904. - Lectotype (designated here): $P$. 
bartramioides (Griffith) D.G. Griffin \& W.R. Buck. Synonymized by Griffin \& Buck (1989).

Comparison of the names in O'Shea's $(1995,2006)$ list of Philonotis taxa with Brotherus (1924) systematic grouping reveals that the African species of the section Philonotula are much more common than the species in the sections "Leiocarpus" and "Eu-Philonotis". Some of them have already been synonymized with species such as $P$. hastata. Philonotis falcata and $P$. hastata are rather easy to distinguish and have been illustrated and discussed in many papers (see below), and Magill (1987) and Ochyra (1993) for southern Africa.

\section{Philonotis hastata (Duby) Wijk \& Margad.}

Taxon 8: 74. 1959. - Hypnum hastatum Duby in Moritzi, Syst. Verz. Zoll. Pfl. 132. 1846. - Type: Indonesia. Java, ad rupes fl. Tjappus, 1813 Zollinger (L 910, 104-376, not seen; cf. Iwatsuki, 1977).

Philonotis marangensis Broth., Bot. Jahrb. 14: 252. 1897. - Holotype: Tanzania. Kilimandscharo, wiss. Station Maranga, am rande einer Wasserleitung, $1580 \mathrm{~m}$, 11.7.1893, häufig, leg. G. Volkens 590 (H-BR3088012!). - Synonymized by Sim (1926).

Descriptions and illustrations: Iwatsuki, 1977: 14, figs. a-o, drawn from the type of P. hastata; Magill, 1987: 426, fig. 122: 15-26; Koponen \& Norris, 1996: 8, fig. 3; Eddy, 1996: 231, fig. 487, 232, fig. 488 A-D.

Philonotis hastata has been reported from many countries in southern and central Africa (O'Shea, 1995, 2006) and many times from Tanzania (Kis, 1985). According to Magill (1987), P. hastata is quite variable especially in leaf length and shape of the apex. He found that the rounded apices are rare in African plants (e.g. the type of P. obtusata Müll.Hal.) and thought that the rounded apices represent only an environmental modification. This is a difference to SE Asiatic plants in which the leaf apex is commonly obtuse (the type of P. hastata, and references above), and especially the innovation leaves tend to be obtuse. In P. marengensis the innovation leaves are acute. Since the cellular details and the leaf margins are identical, I follow Magill's (1987) concept of the species. All Brotherus' herbarium specimens listed below represent plants with rather narrow, long acuminate and arcuate leaves and are identical with the type of $P$. marangensis, and were so named by V.F. Brotherus, except $A$. Engler 432 and $R$. ?spmann 16 (H-BR3088025).

Specimens studied: TANZANIA. Kilimandscharo, Marangu-Station, häufig in der Culturregion, bildet auf Steinen in und an den Böschungen am Wasser dichte Polster, $1580 \mathrm{~m}$, 8.5.1894 G. Volkens 2279 (H-BR3088027); Oberhalb Kiboscho, am und in Wasser, $2000 \mathrm{~m}, 25.10 .1901$ C. Uhlig (H-BR 3088024); Deutsch Ostafrika, Moshi am Kilimandscharo, Erde, 9.1908 R. ?spmann 16 (H-BR3088025, ex herb. M. Spindler, as P. obtusa); Meru, Solam Bach, 14.11.1901 C. Uhlig (HBR3088043, as P. gemmascens); Ost-Usambara, Amani, an einer Quelle im Kwamkuyutale, 800 m, 8.8.1909 J. Brunnthaler (H-BR3088033); Amani, 8.1910 Br. Schroeder 57 (HBR3088029); Ost-Usambara, unterer immergrünes Schluchten- wald zur Lungusa und Darema, 4-600 m, 13.9.1902 A. Engler 432 (H-BR3088028, as Philonotis recurvata Broth. n.sp.).

\section{Philonotis schroederi Broth}

Hedwigia 52: 310. 1912. - Holotype: Tanzania. Kilimandscharo, von Marangu nach Moschi, 9.IX.1910 Br. Schroeder 131 (H-BR3084011!).

Plants small, ca. $0.7 \mathrm{~mm}$ tall, brownish; leaves erect and imbricate when dry, smooth, 1-1.8 mm long and 0.5$0.8 \mathrm{~mm}$ broad at base, from ovate base gradually narrowing to acute apex; costa ca. $30 \mu \mathrm{m}$ broad near base, excurrent, with blunt teeth at apical part, innovation leaves smaller and similar to growth leaves; leaf areolation translucent at lower half; leaf margin plane, marginal cells subquadrate and smooth at base, geminate at mid-leaf and serrate near apex; no specialized alar cells present; basal leaf cells bulging at proximal cell end, \pm rectangular, 10-15×15-45 $\mu \mathrm{m}$, mid-leaf cells linear, distinctly papillose at distal cell end, $5-10 \times 25-50 \mu \mathrm{m}$.

Dioicous. Perichaetial leaves from ovate translucent base abruptly narrowing to an acuminate apex; papillosity as in growth leaves. Seta $1-1.5 \mathrm{~cm}$ long, slender; capsule 1-2 mm, erect, smooth, globose and with exerted mouth. Operculum slightly concave. Inner peristome lacking; outer peristome reduced, fragile. Male plants not seen.

Brotherus (1924) placed Philonotis schroederi in the section Leiocarpus which was synonymized with the section Bartramidula by Griffin \& Buck (see above). $P$. schroederi has the characters by which the species of the section Bartramidula have been traditionally separated from the species of the sections Philonotis and Philonotula: \pm erect, globose capsule and reduced peristome. A character common with the East Asiatic species of Bartramidula (Koponen, 2010b, 2014) and P. schroederi are the wide basal leaf cells with mammilla bulging at the proximal cell ends. However, the same character is present in some species of the section Philonotula as well, e.g. in P. vescoana (Besch.) Par. (Koponen \& Norris, 1996; Koponen, 2014). P. hastata is about the size of P. schroederi. The specimens without capsules can be separated by the narrow apical leaf cells in $P$. schroederi versus rather wide leaf cells in all parts of the leaf in P. hastata.

\section{Philonotis gemmascens (Müll.Hal.) Par.}

Ind. Bryol. 922. 1897. - Bartramia gemmascens Müll.Hal., Flora 73: 479. 1890. - Lectotype (designated here): [From the protologue:] Africa or. trop., monte Kilima-Ndscharo, Marango, in planitie graminosa superiore inter 1800-3000 m: Dr. Hans Meyer 1889; [from specimen:] Philon. gemmascens (C.M.), leg. H. Meyer (H-BR3088017!)

The specimen in H-BR contains only one shoot ca. 1 $\mathrm{cm}$ tall, and was studied only under the dissecting microscope. The leaves are narrow lanceolate with acuminate apex. Brotherus (1924) placed P. gemmascens to the section Pilonotula, and the cellular detail "cellulis 
minutis ... parce et minutissime papillosa" (Müller, 1890) agrees with placing it in the section Philonotula. Another specimen, C. Uhlig (H-BR3088043) under that name in H-BR is $P$. hastata (see above).

Many names of the African taxa of the section Philonotula are older than Philonotis gemmascens (1897). Therefore, the correct name for P. gemmascens cannot yet be confirmed.

\section{Philonotis globosa (Müll.Hal.) D.G. Griffin \& W.R Buck}

Bryologist 92: 376. 1989. - Bartramia globosa Müll.Hal., Hedwigia 38: 90. 1899. Bartramidula globosa (Müll.Hal.) Broth., Nat. Pfl.1(3): 644. 1904.

Bizot \& Pocs (1982) recorded Philonotis globosa (as Bartramidula globosa) from Mt. Kilimanjaro. The other species with globose capsule from Mt. Kilimanjoro is $P$. schroederi (see above) Brotherus $(1909,1924)$ kept $P$. globosa in the genus Bartramidula but placed P. schroederi in the Philonotis section Leiocarpus. The difference between these two seems to be that the species of Bartramidula are eperistomate and the species of Leiocarpus have an outer peristome. The study of the gametophytic characters of $P$. globosa is necessary to confirm the possible synonymy of $P$. schroederi with $P$. globosa.

\section{Philonotis dregeana (Müll.Hal.) A. Jaeger}

Ber. S. Gall. Naturw, Ges. 1873-74: 89. 1875 (Ad. 1: 551). - Bartramia dregeana Müll.Hal., Bot. Zeit. 14: 419. 1856.

O'Shea (2006) gave Philonotis dregeana for Tanzania citing Kis (1985), where it is not included. However, Pócs (1994) listed it in his paper on the altitudinal distribution of Kilimanjaro bryophytes. I have not yet seen specimens of $P$. dregeana from Mt. Kilimanjaro.

\section{NOTES OF SOME OTHER AFRICAN PHILONOTIS}

\section{Philonotis falcata (W.J. Hook.) Mitt.}

J. Linn. Soc. Bot. Suppl. 1: 62. 1859. - Bartramia falcata W.J. Hook., Trans. Linn. Soc. London 9: 317, 27 f. 4. 1808. - Philonotis fontana var. falcata (W.J. Hook.) Brid., Bryol. Univ. 2: 21. 1827. - Lectotype: Nepal, coll. Dr. Buchanan (BM!, ex herb. Hooker, ex herb. Kew, "Dr. Smith 1808, No. H/2359"; isolectotypes in BM!, ex herb. Dawson Turner, ex herb. Hooker; FH!, ex herb. Mitten, ex herb. Hooker). - Designated by Koponen (2012).

Desriptions and illustrations: Ochi, 1962: pl. 4, figs. A-D, drawn from the type of P. falcata; Ochi, 1962: pl. 5 , figs. A-F, drawn from the type of $P$. carinata; Koponen, 1996: 115, fig. 1; Koponen, 2012: 154, fig. 1; Kürschner \& Ochyra, 1999: 272, fig. 2; Eddy, 1996: 234, fig. 489; 235, fig. 490, as P. turneriana.

Philonotis falcata has not been recorded from Tanzania but is known from adjoining countries Malawi, Rwanda, Zaire and Zambia (O'Shea, 1995, 2006). Its range extends from southern Africa (range map in Magill, 1987) through SW Asia (Kürschner \& Ochyra, 1999,
Koponen, 2012) to India and Japan (range map in Koponen, 1996, 2003).

\section{Philonotis usambarica Broth.}

Hedwigia 52: 311. 1912. - Holotype: Tanzania, OstUsambara, immergrüner Regenwald in Schluchten zw. Amani and Kwamkoro, 800 m, 19.9.1902 A. Engler 818 (H-BR3088015!).

Philonotis usambarica is a very small species with small $(1.8 \mathrm{~mm})$ long, horizontal, ovate to gibbous and striate capsules with complete peristome. The leaf cells are firm-walled, rectangular and nearly smooth, only slightly bulging at the distal cell corner. It resembles $P$. hastata in having the leaf cells wide throughout the leaf, and not narrow and elongate as in most of the species of the section Philonotula. A special character of P. usambarica is the very rough dorsal costa by large teeth, not seen by me until now in any other Philonotis specimens.

Philonotis heleniana (Mitt.) Herz.

Biblioth. Bot. 73: 51. 1910. - Bartramia heleniana Mitt. in Mell., St. Helena 361. 1875. - Type: "Burchell, specimen marked Bartramia Heleniana, Burchell" (not seen).

The protologue of the taxon is short and the discussion connects the taxon to Philonotis fontana: "If this specimen had not been marked by Burchell, it would have been perhaps better to have passed it over as a state of $B$. fontana until more could have been learnt respecting it. In size it appears to be a little smaller than the common states of B. fontana". Paris (1904) synonymized Philonotis heleniana with Philonotis fontana, and his decision was followed by Wijk et al. (1959) and by O'Shea (1996, 2006). On the basis of the phytogeography of $P$. fontana its presence on St. Helena is not probable (see Koponen et al., 2014).

\section{Philonotis helenica (Besch.) Par.}

Ind. Bryol. 923. 1896. - Philonotula helenica Besch., J. Bot. 5: 144. 1881. - Bartramia helenica (Besch.) Müll.Hal., Gen. Musc. Fr. 339. 1900. - Isotype: St. Hélena, 1872 Balansa (H-BR3087025!, ex Herb. Mus. Paris)

The specimen represents a specimen of Philonotis section Philonotula.

\section{ACKNOWLEDGEMENTS}

I wish to thank professors Tamás Pócs (Eger) and Ryszard Ochyra (Krakow) for sending material for this research, and Sinikka Piippo for valuable comments on the manuscript.

\section{LITERATURE CITED}

BIZOT, M. \& PÓCS, T. 1982. East African Bryophytes, V. - Acta Botanica Academiae Scientiarum Hungaricae 28: 15-64.

BROTHERUS V.F. 1909. Musci; Unterklasse Bryales. - In: Engler, A. (Ed.), Die natürlichen Pflanzenfamilien nebst ihren Gattungen und wichtigeren Arten insbesondere den Nutzplanzen, unter Mitwirkung zahlreicher hervorragenden Fachgelehrten begründet von A. Engler und K. Prantl 1(3), II Hälfte. W. Engelmann, Leipzig: 529-1246. 
BROTHERUS, V.F. 1924. Musci (Laubmoose). II. Spezieller Teil. - In: Engler, A. \& Prantl, K. (Ed.) Die natürlichen Pflanzenfamilien nebst ihren Gattungen und wichtigeren Arten insbesondere den Nutzpflanzen. 2. Aufl. 10 (1): 129-131, 143-478.

EDDY, A. 1996. A handbook of Malesian mosses. 3. Splachnobryaceae to Leptostomataceae. - The Natural History Museum, London: 277 pp.

GRIFFIN, D. III \& W.C. BUCK. 1989. Taxonomic and phylogenetic studies on the Bartramiaceae. - Bryologist 92: 368-380

IWATSUKI, Z. 1977. Notes on Philonotis hastata (Duby) Wijk \& Marg. in Japan. - Proceedings of the Briological Society of Japan 2: 13-15.

KIS, G. 1985. Mosses of south-east tropical Africa. - Institute of Ecology and Botany of the Hungarian Academy of Sciences, Vacratot: $170 \mathrm{p}$.

KOPONEN, T. 1996. Notes on Philonotis (Bartramiaceae, Musci). 1. Status and distribution of Philonotis falcata. - Arctoa 6: 113-117.

KOPONEN, T. 1998. Notes on Philonotis (Musci, Bartramiaceae). 3. A synopsis of the genus in China. - Journal of the Hattori Botanical Laboratory 84: 21-27.

KOPONEN, T. 2003. Notes on Philonotis (Musci, Bartramiaceae), 5. P. caespitosa, and $P$. falcata in South Africa, and status of $P$. afrocapillaris. - Acta Academie Paedagogicae Agriensis Sectio Biologicae. 24: 29-42.

KOPONEN, T. 2009. Notes on Philonotis (Bartramiaceae, Musci). 6. Key to Japanese Philonotis and Fleischerobryum. - Hikobia 15: 271-280.

KOPONEN, T. 2010a. Notes on Philonotis (Bartramiaceae, Musci). 7. Key to Chinese Philonotis and Fleischerobryum. - Tropical Bryology 31: 126-130.

KOPONEN, T. 2010b. Notes on Philonotis (Bartramiaceae, Musci). 8. Philonotis in William Mitten's "Musci Indiæ orientalis" and key to southeast Asian taxa. - Acta Bryolichenologica Asiatica 3: 69-90.

KOPONEN, T. 2012. Notes on Philonotis (Bartramiaceae, Musci). 12. Philonotis laxitexta is P. falcata, new to Iran. - Polish Botanical Journal 57: 153-155.

KOPONEN, T. 2014. Notes on Philonotis (Bartramiaceae, Musci). 13. Status of Philonotis minutifolia, $P$. pilifera, . seriata var. persica, $P$. tjibodensis, P. treubii and P. turneriana var. robusta. - Acta Bryolichenologica Asiatica 5: 133-140.

KOPONEN, T., E.A. IGNATOVA, O.I. KUZNETSOVA \& M.S. IGNATOV. 2012. Philonotis (Bartramiaceae, Musci) in Russia. - Arctoa 21: $21-62$.

KOPONEN, T. \& D.H. NORRIS. 1996. Bryophyte flora of the Huon Peninsula, Papua New Guinea. LVII. Fleischerobryum and Philonotis
(Bartramiaceae, Musci). - Acta Botanica Fennica 156: 1-21.

KOPONEN, T., S. PIIPPO \& J. ENROTH. 2014. Principles of checklists. Revised version. - Acta Bryolichenologica Asiatica 5: 151-155.

KÜRSCHNER, H. \& R. OCHYRA. 1999. Two remarkable hygrophytic mosses new to the bryophyte flora of Yemen (Studies in Arabian bryophytes 25). - Fragmenta Floristica et Geobotanica 44: 269-275.

MAGIL, R.E. 1987. Gigaspermaceae-Bartramiaceae. - In: Leistner, O.A., Flora of southern Africa. Bryophyta, part 1, Mosses. Fascicle 2: viix, 293-443.

MÜLLER, C. 1890. Moose von vier Kilimandscharo-Expeditionen. -Flora 73: 465-499.

OCHI, H. 1962, 1963. Contributions to the mosses of Bartramiaceae in Japan and the adjacent regions 1, 2. - Nova Hedwigia 4: 87-108, Tab. 38-49; 5: 91-115, Tab. 9-26.

OCHYRA, R. 1993. Taxonomic results of the BRYOTROP Expedition to Zaire and Rwanda. 20. Grimmiaceae, Funariaceae, Bartramiaceae (Philonotis), Amblystegiaceae, Plagiotheciaceae. - Tropical Bryology 8: $181-187$.

OCHYRA, R., R.I.L. SMITH \& H. BEDNAREK-OCHYRA. 2008. The illustrated moss flora of Antarctica. - Cambridge University Press: xvii, $685 \mathrm{p}$.

O'SHEA, B.J. 1995. Checklist of the mosses of sub-Saharan Africa. Tropical Bryology 10: 91-198.

O'SHEA, B.J. 2006. Checklist of the mosses of sub-Saharan Africa. (Version 5, 6/12). - Tropical Bryology Research Report 6: 1-252.

PARIS, É.G. 1904. Index bryologicus. Ed. 2. - Librairie scientifique A. Hermann, Paris. 2: 1-375.

PÓCS, T. 1994. The altitudinal distribution of Kilimanjaro bryophytes. In: Seyani, J.H. \& Chikuni, A.C. (eds.), Proc. XIIIth Plenary Meeting AETFAT, Malawi 2: 797-812.

POTIER DE LA VARDE, R. 1957: Mousses récoltées par M. le Dr. Olov Hedberg, en Afrique orientale, au cours de la mission suédoise de 1948. - Arkiv för Botanik. 3, Ser. 2: 125-204.

SIM, T.R. 1926. The bryophyta of South Africa. - The Royal Society of South Africa. Cape Town: iii, $475 p$.

VIRTANEN, V. 2003. Phylogeny of Bartramiaceae (Bryopsida) based on morphology and on rbcL, rps4, and trnL-trnF sequence data. - Bryologist 106: 280-296.

WIJK VAN DER, R., W.D. MARGADANT \& P.A. FLORSCHÜTZ. 1967. Index muscorum. Vol. IV (P-S). - Regnum Vegetabile 48: 1-604. 